\title{
Response surface methodology and optimization of the processes for bioethanol production from Calabash (Crescentia cujete) Using Cronobacter malonaticus
}

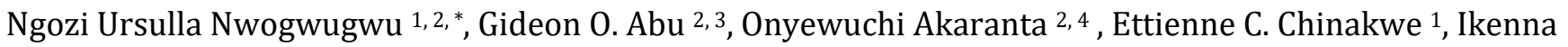
N.Nwachukwu ${ }^{1}$, Obioma K.Mejeha ${ }^{1}$ and Chinedu E.Ihejirika ${ }^{5}$

${ }^{1}$ Department of Microbiology, Federal University of Technology, Owerri, Nigeria.

${ }^{2}$ Centre for Oil Field Chemicals Research, University of Port Harcourt, Nigeria.

${ }^{3}$ Department of Microbiology, University of Port Harcourt, Port Harcourt, Nigeria.

${ }^{4}$ Department of Pure and Applied Chemistry, University of Port Harcourt, Nigeria.

${ }_{5}^{5}$ Department of Environmental Technology, Federal University of Technology, Owerri, Nigeria.

GSC Biological and Pharmaceutical Sciences, 2021, 14(02), 204-216

Publication history: Received on 15 January 2021; revised on 31 January 2021; accepted on 02 Februay 2021

Article DOI: https://doi.org/10.30574/gscbps.2021.14.2.0019

\begin{abstract}
Aim: Response surface methodology (RSM) model was applied to optimize ethanol production from Calabash (Crescentia cujete) pulp juice using Cronobacter malonaticus.

Study Design: The Calabash pulp was squeezed with muslin cloth, and vacuum filtered to clear solution before use. The clear juice was tested for reducing sugars using the Dinitrosalicylic acid (DNS) method. Twenty three (23) runs, including 3 controls, of the fermentation was conducted at varying temperatures, $\mathrm{pH}$, and volumes of inoculum. The process parameters (input variables): volumes of inoculum, temperature, and $\mathrm{pH}$ were subjected to response surface model, using the Central Composite Design (CCD).
\end{abstract}

Place and Duration of Study: This study was carried out in the Environmental Microbiology Laboratory, University of Port Harcourt for six months.

Methodology: Fermentation was done in conical flasks covered with cotton wool and foil in a stationary incubator for four days (96 hours). Active stock culture of Cronobacter malonaticus was used, with inoculum developed using Marcfaland's method. Samples were collected every 24 hours, centrifuged, filtered and analyzed for measurement of the output variables: Reducing sugar, cell density and ethanol concentration.

Results: The concentration of reducing sugars from Calabash pulp was $3.2 \mathrm{mg} / \mathrm{ml}$. Results obtained also revealed that the fermentation can take place on a wide range of temperature $28-32^{\circ} \mathrm{C}$. The optimal $\mathrm{pH}$ range for performance of C.malonaticus for the fermentation process was $\mathrm{pH}$ 5.95-6.5. The optimum volume of inoculum was $10 \% \mathrm{v} / \mathrm{v}$ (i.e. $10 \mathrm{ml}$ in $90 \mathrm{ml}$ juice). The optimized process using the RSM model gave $5.08 \% \mathrm{v} / \mathrm{v}$ bioethanol, being the highest achieved at pH6.08 and $28^{\circ} \mathrm{C}$.

Conclusion: The bioethanol yield from Calabash substrate is reasonable considering that the bacterium used is not known for ethanol production. Also the concentration of reducing sugars in the substrate and the duration of fermentation could be responsible for the yield.

Keywords: Calabash juice; Fermentation; Optimization; Response Surface Methodology and Bioethanol

\footnotetext{
* Corresponding author: Ngozi Ursulla Nwogwugwu

Department of Microbiology, Federal University of Technology, Owerri, Nigeria.
} 


\section{Introduction}

The world's current energy supply may be depleted because fossil fuels are non-renewable. This, amongst other reasons call for search into alternative energy sources. Such energy sources include: solar energy, nuclear energy, wind energy, hydropower, tidal energy and biofuels [1; 2]. Biofuels include biogas and bioethanol, mostly produced from plant and animal materials with the action of microorganisms [3; 2].Sugar sources and cellulosic materials such as sugar cane, corn, wheat, grasses and woody crops, respectively have been widely used in bioethanol production. It has been established that these materials have attendant problems such as interfering with food supply, and the pretreatment methods required $[4 ; 5]$.

Bioethanol has high economic value as a solvent, a germicide, a beverage, an anti-freeze, a fuel, and a depressant [6]. Bioethanol can be used as a partial gasoline replacement in some countries of the world [1]. It contains 35\% oxygen in its chemical molecule, useful in complete combustion of fuel and lowers emission of harmful gases in compressionignition engines [3].

The substrate used in this study was fresh pulp juice from Calabash (Crescentia cujete) fruit. This fruit is underutilized, but has the rare potential of fruiting all through the year; with the characteristic large, round fruit of 12-14 cm in diameter [7]. It has been established that the fruit contains fermentable sugars [8; 9]; hence the basis for use in the production of bioethanol in this work.

The fermenting organism, Cronobacter malonaticus was recently identified from reclassification of Enterobacter sakazaki, a member of the Enterobacteriaceae family. Cronobacter species are primary inhabitants of plant materials, like their counterpart Enterobacter species, hence the isolation from rotten orange. The members of the genus are facultatively anaerobic, gram-negative, oxidase-negative, catalase positive, motile and produce acetoin (VogesProskauer positive and Methyl red test negative).They ferment D-glucose and other sugars yielding acid and gas; produce aldehydes, ketones, alcohols, sulfur compounds[10]. They metabolize glucose through the 2, 3-butanediol fermentative pathway [10].

The optimization of the process was done using the Response Surface Methodology (RSM) Model. This method compares relationships between multiple variables on the entire fermentation process at the same time. It has been employed in several chemical and biochemical processes to improve optimal yield in the industries [11; 12].

The RSM model used in this study will help provide a benchmark in production processes for future production of bioethanol from Calabash. Since the fruit is produced all year round, and is from a lesser used plant, it can form a sustainable substrate for bioethanol production. It is however necessary that other organic sources be studied for bioethanol production so as to meet our energy demand.

\section{Material and methods}

\subsection{Preparation of the Calabash Juice}

The Calabash fruit was sourced from the garden around homes. They were used as hedges, as well as shades from the sun in most traditional family settings. The pulp juice used in this study was formerly thrown away, while the shell or gourd served as material for containers to store food materials and for musical instrument amongst others. The pulp was squeezed to get the juice out with muslin cloth and heated on an electric plate at $50^{\circ} \mathrm{C}$ for 4 hours to concentrate the juice. It was vacuum filtered using Whatman No 1 filter paper of $12.5 \mathrm{~cm}$ dimension to get it clear. The resulting clear juice was sterilized $121^{\circ} \mathrm{C}$ and 15 psi for 10 minutes and allowed to cool before fermentation was initiated.

\subsection{Isolation of the Microbial Strain}

Cronobacter malonaticus was isolated from rotten orange. Glucose agar medium made up of the following was used: yeast extracts $10 \mathrm{~g} / \mathrm{l}$, glucose $20 \mathrm{~g} / \mathrm{l}$, agar $15 \mathrm{~g} / \mathrm{l}, \mathrm{KH}_{2} \mathrm{PO}_{4} 1 \mathrm{~g}, \mathrm{MgCl}_{2} 1 \mathrm{~g} / \mathrm{l},\left(\mathrm{NH}_{4}\right)_{2} \mathrm{SO}_{4} 1 \mathrm{~g} / \mathrm{l}$, and pH6.0 [2]. The Glucose was filter sterilized and added after other ingredients have been autoclaved. 


\subsection{Molecular Characterization of the Isolate, Cronobacter malonaticus:}

The extraction of DNA and sequencing of 16S rRNA was done. Further phylogenetic analysis was carried out, and sequences were matched with National Biotechnology Information Center (NCBI) database using Blast N, and linked using Clustal X $[12 ; 13]$.

\subsection{Application of Response Surface Methodology (RSM).}

Response surface methodology (RSM) involves a set of mathematical and statistical techniques used to develop functional relationships between a variable of interest referred to as the response/dependent/output variable(y), and a number of associated independent/input/control variables denoted by X1, X2, X3....Xn. This relationship can be represented by a polynomial model as follows:

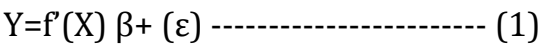

Where $X=(x 1, x 2,-----x n), f^{\prime}(x)$ is a vector function of $\rho$ elements comprising of powers and cross products of powers $x 1, x 2----x n$, reaching to a point denoted by $d(\geq 1), \beta$ is a vector of unknown constant coefficients known as parameters, while $\varepsilon$ is a random experimental error assumed to have a mean of zero.

The expression in equation (1) above is assumed to offer adequate representation of the response: $\mathrm{f}^{\prime}(\mathrm{x}) \beta$ denotes the mean response, which is the expected value of $y$.

It is expected that RSM would help achieve the following:

- Establish an approximate relationship between $\mathrm{y}$ and $\mathrm{x} 1, \mathrm{x} 2$-----xn used to predict response values for given settings of the control variables

- Determine optimum settings of $\mathrm{x} 1, \mathrm{x} 2----\mathrm{xn}$ that result in the maximum (or minimum) response over a certain region of interest.

\subsection{Fermentation of Calabash Pulp Juice}

\subsubsection{Experimental Design:}

Response surface methodology (RSM) model was applied were a set of 23 replicates; including control was used at varying $\mathrm{pH}$ and volumes of inocula (Experiments 1-4). Fermentation of the Calabash juice was run in $250 \mathrm{ml}$ capacity Erlenmeyer flasks containing $100 \mathrm{ml}$ each. Flasks were sterilized at $160^{\circ} \mathrm{C}$ for 1 hour before use. The juice was inoculated with varying amounts of Cronobacter malonaticus inoculum, according to the RSM model, and covered with cotton wool and aluminum foil. They were incubated at temperatures $25^{\circ} \mathrm{C}, 32.5^{\circ} \mathrm{C}$ and $40^{\circ} \mathrm{C}$ for 4 days (96 hours) in a stationary culture. Samples were collected every 24 hours to check for changes in reducing sugar concentrations; $\mathrm{pH}$ and cell density as fermentation was in place.

\subsection{Determination of Reducing Sugars:}

This was done by Dinitrosalicylic acid (DNS) method. A standard curve was created using Standard glucose solution, where the concentration of the unknown sample was derived in $\mathrm{mg} / \mathrm{ml}$. Two milliliter (2ml) of dinitrosalicylic acid (DNS) reagent was added to $1 \mathrm{ml}$ of the sample in a clean test tube. The mixture was put in a boiling water bath for 5 minutes. After cooling, $7 \mathrm{ml}$ distilled water was added, and the absorbance read at 540nm using blank as control

\subsection{Recovery and Determination of Ethanol Concentration}

Distillation method was used to recover the ethanol from the fermentation broth. The broth was poured into roundbottom flask attached to a distillation column surrounded by running water. The distillate was collected in a quick-fit flask at the other end of the distillation column. Temperature of the heating mantle was set at $78^{\circ} \mathrm{C}$.

Determination of ethanol concentration was done by the potassium dichromate method. Plotting of ethanol calibration curve was carried out using $20 \%$ absolute ethanol. Two milliliter $(2 \mathrm{ml})$ of acidified potassium dichromate solution was added to $5 \mathrm{ml}$ of the distillate and allowed to stand for color development. Absorbance was read at 588nm.The ethanol concentration of the distillate was derived from the calibration curve. 


\subsection{Quantitative Determination of Ethanol Concentration by Gas Chromatography (GC-FID).}

Gas-chromatography flame-ionization detector (GC-FID) was run on the distillates to validate the qualitative and quantitative properties of bioethanol. This was done with the GC type: HP589011. The GC was connected to a computer running peak simple software version 2.8 . Oven temperature was set initially at $40^{\circ} \mathrm{C}$ for 2 minutes, $180^{\circ} \mathrm{C}$ final for 5 minutes at $15^{\circ} \mathrm{C} / \mathrm{min}$ and then $300^{\circ} \mathrm{C}$ final at $20^{\circ} \mathrm{C}$. Two micro liter $(2 \mu \mathrm{l})$ samples was mixed with $5 \%$ Acetonitrile at the ratio of 1:1, was injected manually at time zero 0, using a $5 \mu \mathrm{l}$ Hamilton syringe and temperature cycle was started. Ethanol regularly came out at retention time equivalent to $65^{\circ} \mathrm{C}$.

Experiment 1: DAY 1

Cronobacter malonaticus

\begin{tabular}{|c|c|c|c|c|c|c|}
\hline Run & pH & $\begin{array}{l}\text { Temp } \\
\left({ }^{\circ} \mathrm{C}\right)\end{array}$ & Vol.(ml) & $\begin{array}{l}\text { Cell } \quad \text { Density } \\
\text { (OD) }\end{array}$ & $\begin{array}{l}\text { Reducing sugar } \\
(\mathrm{g} / \mathrm{l})\end{array}$ & $\begin{array}{l}\text { Ethanol } \\
\text { concentration }(\% \mathrm{v} / \mathrm{v})\end{array}$ \\
\hline 1 & 5.5 & 25 & 13 & 0.433 & 3.224 & 2.476 \\
\hline 2 & 6 & 32.5 & 10 & 0.654 & 3.259 & 2.488 \\
\hline 3 & 6.5 & 25 & 7 & 0.383 & 3.199 & 2.659 \\
\hline 4 & 6 & 32.5 & 7 & 0.630 & 2.961 & 2.391 \\
\hline 5 & 6 & 32.5 & 10 & 0.622 & 3.320 & 2.999 \\
\hline 6 & 6 & 32.5 & 10 & 0.728 & 3.168 & 5.125 \\
\hline 7 & 6 & 32.5 & 10 & 0.531 & 3.479 & 2.889 \\
\hline 8 & 6.5 & 40 & 13 & 0.353 & 3.004 & 0.605 \\
\hline 9 & 6 & 25 & 10 & 0.361 & 3.163 & 2.695 \\
\hline 10 & 6.5 & 32.5 & 10 & 0.582 & 3.608 & 4.323 \\
\hline 11 & 6 & 32.5 & 13 & 0.513 & 3.335 & 2.439 \\
\hline 12 & 6.5 & 40 & 7 & 0.343 & 3.042 & 1.456 \\
\hline 13 & 5.5 & 40 & 7 & 0.255 & 2.931 & 1.055 \\
\hline 14 & 6 & 40 & 10 & 0.412 & 2.961 & 1.115 \\
\hline 15 & 5.5 & 32.5 & 10 & 0.526 & 3.297 & 4.663 \\
\hline 16 & 6 & 32.5 & 10 & 0.518 & 3.289 & 7.312 \\
\hline 17 & 6.5 & 25 & 13 & 0.352 & 3.179 & 2.002 \\
\hline 18 & 6 & 32.5 & 10 & 0.528 & 3.055 & 3.448 \\
\hline 19 & 5.5 & 25 & 7 & 0.365 & 3.204 & 2.185 \\
\hline 20 & 5.5 & 40 & 13 & 0.313 & 2.923 & 0.411 \\
\hline
\end{tabular}


$D A Y 2$

Cronobacter malonaticus

\begin{tabular}{|c|c|c|c|c|c|c|}
\hline Run & pH & $\begin{array}{l}\text { Temp } \\
\left({ }^{\circ} \mathrm{C}\right)\end{array}$ & Vol.(ml) & $\begin{array}{l}\text { Cell Density } \\
\text { (OD) }\end{array}$ & $\begin{array}{l}\text { Reducing sugar } \\
(\mathrm{g} / \mathrm{l})\end{array}$ & $\begin{array}{l}\text { Ethanol concentration } \\
(\% \mathrm{v} / \mathrm{v})\end{array}$ \\
\hline 1 & 5.5 & 25 & 13 & 0.481 & 3.199 & 3.060 \\
\hline 2 & 6 & 32.5 & 10 & 0.680 & 3.042 & 2.889 \\
\hline 3 & 6.5 & 25 & 7 & 0.621 & 3.173 & 2.841 \\
\hline 4 & 6 & 32.5 & 7 & 0.646 & 2.951 & 3.521 \\
\hline 5 & 6 & 32.5 & 10 & 0.650 & 3.299 & 4.348 \\
\hline 6 & 6 & 32.5 & 10 & 0.732 & 3.148 & 5.575 \\
\hline 7 & 6 & 32.5 & 10 & 0.548 & 3.363 & 3.060 \\
\hline 8 & 6.5 & 40 & 13 & 0.450 & 2.921 & 1.650 \\
\hline 9 & 6 & 25 & 10 & 0.607 & 3.123 & 2.780 \\
\hline 10 & 6.5 & 32.5 & 10 & 0.590 & 3.345 & 1.115 \\
\hline 11 & 6 & 32.5 & 13 & 0.530 & 3.227 & 3.448 \\
\hline 12 & 6.5 & 40 & 7 & 0.443 & 2.885 & 2.926 \\
\hline 13 & 5.5 & 40 & 7 & 0.452 & 2.905 & 1.893 \\
\hline 14 & 6 & 40 & 10 & 0.672 & 2.893 & 2.258 \\
\hline 15 & 5.5 & 32.5 & 10 & 0.542 & 3.204 & 3.205 \\
\hline 16 & 6 & 32.5 & 10 & 0.580 & 3.280 & 5.903 \\
\hline 17 & 6.5 & 25 & 13 & 0.625 & 3.148 & 2.197 \\
\hline 18 & 6 & 32.5 & 10 & 0.556 & 3.047 & 3.436 \\
\hline 19 & 5.5 & 25 & 7 & 0.638 & 3.173 & 3.230 \\
\hline 20 & 5.5 & 40 & 13 & 0.484 & 2.895 & 2.439 \\
\hline
\end{tabular}

$D A Y 3$

Cronobacter malonaticus

\begin{tabular}{|l|l|l|l|l|l|l|}
\hline Run & $\mathbf{p H}$ & Temp ( $\left.{ }^{\circ} \mathrm{C}\right)$ & Vol.(ml) & $\begin{array}{l}\text { Cell Density } \\
(\mathbf{O D})\end{array}$ & $\begin{array}{l}\text { Reducing sugar } \\
\mathbf{( g / \mathbf { l } )}\end{array}$ & $\begin{array}{l}\text { Ethanol concentration } \\
(\% \mathbf{\%} / \mathbf{v})\end{array}$ \\
\hline 1 & 5.5 & 25 & 13 & 0.531 & 2.948 & 5.089 \\
\hline 2 & 6 & 32.5 & 10 & 0.702 & 3.778 & 3.728 \\
\hline 3 & 6.5 & 25 & 7 & 0.746 & 3.100 & 6.085 \\
\hline 4 & 6 & 32.5 & 7 & 0.650 & 3.138 & 3.800 \\
\hline 5 & 6 & 32.5 & 10 & 0.656 & 3.118 & 4.699 \\
\hline 6 & 6 & 32.5 & 10 & 0.738 & 2.865 & 5.915 \\
\hline 7 & 6 & 32.5 & 10 & 0.556 & 3.133 & 3.582 \\
\hline 8 & 6.5 & 40 & 13 & 0.665 & 2.415 & 1.395 \\
\hline
\end{tabular}




\begin{tabular}{|l|l|l|l|l|l|l|}
\hline 9 & 6 & 25 & 10 & 0.674 & 3.133 & 4.530 \\
\hline 10 & 6.5 & 32.5 & 10 & 0.604 & 3.279 & 2.318 \\
\hline 11 & 6 & 32.5 & 13 & 0.562 & 3.113 & 3.947 \\
\hline 12 & 6.5 & 40 & 7 & 0.655 & 2.379 & 2.671 \\
\hline 13 & 5.5 & 40 & 7 & 0.673 & 2.596 & 1.723 \\
\hline 14 & 6 & 40 & 10 & 0.674 & 2.582 & 2.002 \\
\hline 15 & 5.5 & 32.5 & 10 & 0.568 & 3.082 & 3.655 \\
\hline 16 & 6 & 32.5 & 10 & 0.588 & 3.103 & 6.158 \\
\hline 17 & 6.5 & 25 & 13 & 0.643 & 3.158 & 4.165 \\
\hline 18 & 6 & 32.5 & 10 & 0.562 & 3.022 & 3.800 \\
\hline 19 & 5.5 & 25 & 7 & 0.645 & 3.034 & 4.894 \\
\hline 20 & 5.5 & 40 & 13 & 0.624 & 2.592 & 2.318 \\
\hline
\end{tabular}

DAY 4

Cronobacter malonaticus

\begin{tabular}{|c|c|c|c|c|c|c|}
\hline Run & pH & $\begin{array}{l}\text { Temp } \\
\left({ }^{\circ} \mathrm{C}\right)\end{array}$ & Vol.(ml) & $\begin{array}{l}\text { Cell Density } \\
\text { (OD) }\end{array}$ & $\begin{array}{l}\text { Reducing sugar } \\
(\mathrm{g} / \mathrm{l})\end{array}$ & $\begin{array}{l}\text { Ethanol concentration } \\
(\% \mathrm{v} / \mathrm{v})\end{array}$ \\
\hline 1 & 5.5 & 25 & 13 & 0.601 & 2.268 & 3.011 \\
\hline 2 & 6 & 32.5 & 10 & 0.704 & 3.381 & 3.849 \\
\hline 3 & 6.5 & 25 & 7 & 0.799 & 2.294 & 4.250 \\
\hline 4 & 6 & 32.5 & 7 & 0.656 & 3.118 & 4.019 \\
\hline 5 & 6 & 32.5 & 10 & 0.660 & 2.849 & 4.894 \\
\hline 6 & 6 & 32.5 & 10 & 0.742 & 3.123 & 6.085 \\
\hline 7 & 6 & 32.5 & 10 & 0.561 & 3.224 & 3.995 \\
\hline 8 & 6.5 & 40 & 13 & 0.870 & 2.061 & 1.395 \\
\hline 9 & 6 & 25 & 10 & 0.681 & 2.271 & 4.274 \\
\hline 10 & 6.5 & 32.5 & 10 & 0.608 & 2.865 & 2.561 \\
\hline 11 & 6 & 32.5 & 13 & 0.571 & 3.027 & 4.092 \\
\hline 12 & 6.5 & 40 & 7 & 0.862 & 2.341 & 2.524 \\
\hline 13 & 5.5 & 40 & 7 & 0.851 & 1.990 & 1.832 \\
\hline 14 & 6 & 40 & 10 & 0.861 & 1.965 & 1.966 \\
\hline 15 & 5.5 & 32.5 & 10 & 0.580 & 3.052 & 4.044 \\
\hline 16 & 6 & 32.5 & 10 & 0.602 & 3.072 & 6.498 \\
\hline 17 & 6.5 & 25 & 13 & 0.744 & 2.172 & 3.558 \\
\hline 18 & 6 & 32.5 & 10 & 0.570 & 2.991 & 4.092 \\
\hline 19 & 5.5 & 25 & 7 & 0.754 & 2.106 & 4.724 \\
\hline 20 & 5.5 & 40 & 13 & 0.865 & 2.084 & 2.233 \\
\hline
\end{tabular}




\section{Results}

\subsection{Identification of the Microbial Strain}

Morphological and biochemical characteristics of the isolate were used for its identification (Table 1).

Molecular characterization technique used was gene sequencing which showed that the isolate has close evolutionary relationship to Cronobacter malonaticus (Fig 1).

Table 1 Morphological and Biochemical Characteristics of the isolate from rotten Orange

\begin{tabular}{|l|l|}
\hline Test/ Attribute & Remark \\
\hline Colonial Characteristics & Mucoid, creamish, umbonate elevation \\
\hline Gram Reaction & $-\quad$ Rod \\
\hline Biochemical Tests & \multicolumn{1}{|c|}{+} \\
\hline Catalase & - \\
\hline Indole & - \\
\hline Urease & \\
\hline Oxidase & AG \\
\hline Fermentation Tests & AG \\
\hline Glucose & AG \\
\hline Fructose & - \\
\hline Sucrose & - \\
\hline Maltose & AG \\
\hline Lactose & Cronobacter malonaticus \\
\hline Mannitol & no fermentation; AG Acid/Gas production \\
\hline Microorganism & Key: + positive; -negative \\
\hline
\end{tabular}

Key: + positive; -negative/ no fermentation; AG Acid/ Gas production

\subsection{Concentration of Reducing Sugars}

This was deduced from the calibration curve with the mean absorbance value gotten as 1.240 at $540 \mathrm{~nm}$. The equation from the standard curve is given as:

$y=0.3955 x-0.0355$

Hence, Reducing sugar $=3.22 \mathrm{mg} / \mathrm{ml}$.

\subsection{Determination of Ethanol Concentration}

Ethanol concentrations were extrapolated from the calibration curve.

The equation was given as:

$y=0.0823 x+0.0352$ 


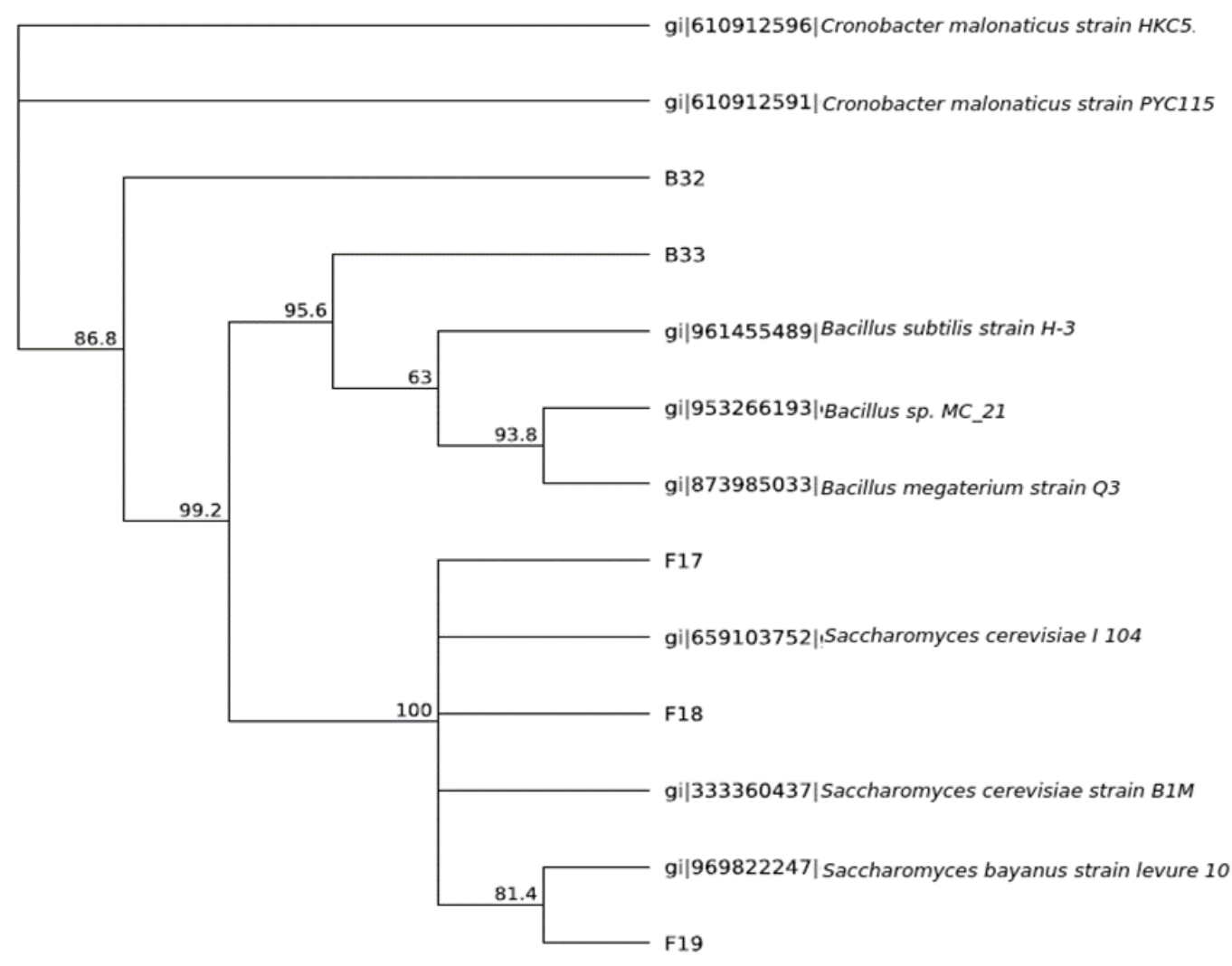

Figure 1 Evolutionary relationship amongst the bacterial isolates

\subsection{Optimization of the Process Parameters using RSM}

The optimization process yielded results as expressed in Tables 2 and 3, as well as Figures 2-4. The volume of inoculum was kept constant at 10\%. Optimal temperature of performance ranged from 28-32oC, while pH was 5.95-6.5.The cell density during the four- day period increased from $0.57-0.66$ on day 3 , and slightly reduced to 0.63 on the fourth day(Fig. 2). The reducing sugar levels decreased steadily from $3.5 \mathrm{~g} / \mathrm{l}$ on day 1 to $2.9 \mathrm{~g} / \mathrm{l}$ on day 4(Fig. 3). Ethanol concentration of $5.08 \% \mathrm{v} / \mathrm{v}$ was recorded on day 3 , with a desirability value of 0.9 (Table 2).

Table 2 Optimized variables for Calabash Pulp Juice fermented using Cronobacter malonaticus

\begin{tabular}{|l|l|l|l|l|l|l|l|}
\hline Time & $\mathbf{p H}$ & $\begin{array}{l}\text { Temp. } \\
\left(\mathbf{}{ }^{\circ} \mathbf{C}\right)\end{array}$ & $\begin{array}{l}\text { Volume } \\
(\mathbf{m l})\end{array}$ & $\begin{array}{l}\text { Cell density } \\
(\mathbf{O D})\end{array}$ & $\begin{array}{l}\text { Reducing } \\
\text { sugar }(\mathbf{g} / \mathbf{l})\end{array}$ & $\begin{array}{l}\text { Ethanol } \\
\text { conc.(\%v/v) }\end{array}$ & $\begin{array}{l}\text { Desirability } \\
\left(\mathbf{d}_{\mathbf{i}} \mathbf{)}\right.\end{array}$ \\
\hline Day 1 & 6.50 & 32.0 & 10 & 0.5718 & 3.50 & 4.748 & $0.751(75.1 \%)$ \\
\hline Day 2 & 6.00 & 31.0 & 10 & 0.6368 & 3.2075 & 3.8362 & $0.823(82.3 \%)$ \\
\hline Day 3 & 6.08 & 28.0 & 10 & 0.6607 & 3.217 & 5.0819 & $0.911(91.1 \%)$ \\
\hline Day 4 & 5.95 & 28.6 & 10 & 0.6291 & 2.8672 & 4.8330 & $0.876(87.6 \%)$ \\
\hline
\end{tabular}

Desirability values close to 1 depict higher probability of achieving optimal response. Also the coefficient of determination $\mathrm{R}^{2}$ (goodness of fit) measures the level of variability of the response variable that the control variables could explain (Table 3 ). The values of $R^{2}$ lie between 0 and $1\left(0 \leq R^{2} \leq+1\right)$. The closer the $R^{2}$ value is to 1 , the more predictive or reliable the model is. 
Table 3 Goodness of fit $\left(\mathrm{R}^{2}\right)$ for Calabash juice fermented with Cronobacter malonaticus.

\begin{tabular}{|l|l|l|l|l|}
\hline Fermentation Period & Model & Cell density & Reducing sugar & $\begin{array}{l}\text { Ethanol } \\
\text { concentration }\end{array}$ \\
\hline Day 1 & Quadratic & 0.8417 & 0.6899 & 0.6583 \\
\hline Day 2 & Quadratic & 0.6186 & 0.6186 & 0.4790 \\
\hline Day 3 & Quadratic & 0.5518 & 0.5518 & 0.7175 \\
\hline Day 4 & Quadratic & 0.8605 & 0.7496 & 0.6857 \\
\hline
\end{tabular}

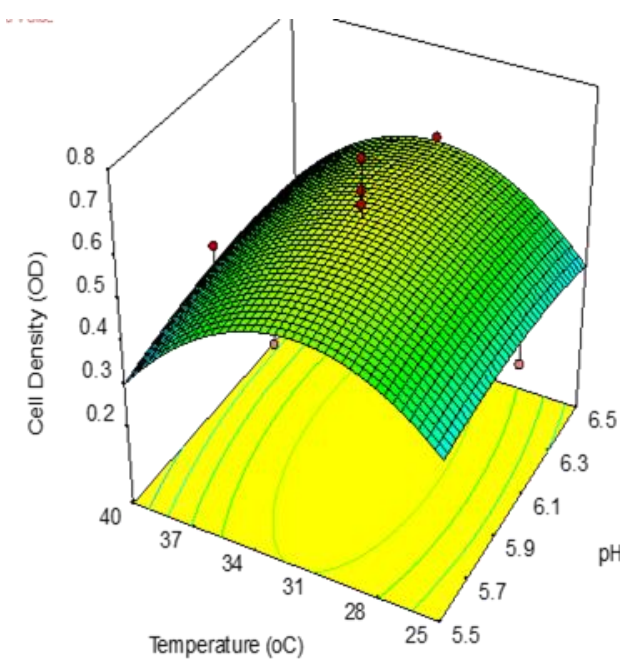

Day 1

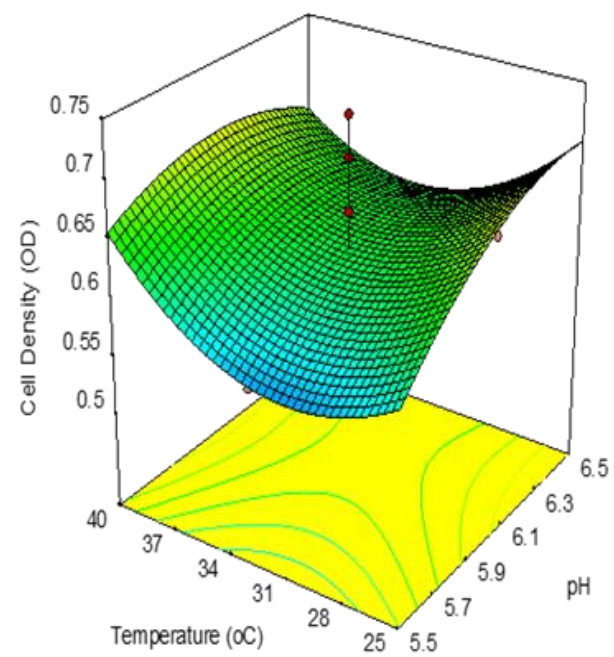

Day 3

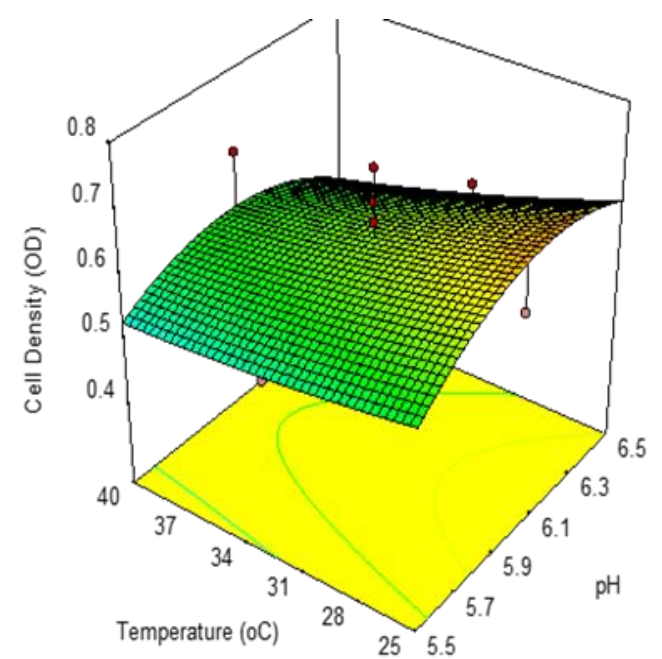

Day 2

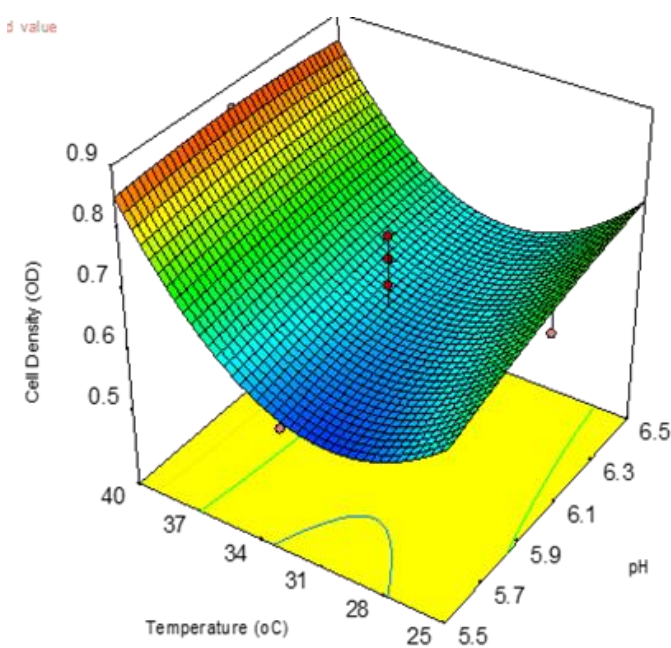

Day 4

Figure 2 Response surface attributes of Cell density (OD) of Cronobacter malonaticus during Calabash fermentation for 4 days 
GSC Biological and Pharmaceutical Sciences, 2021, 14(02), 204-216

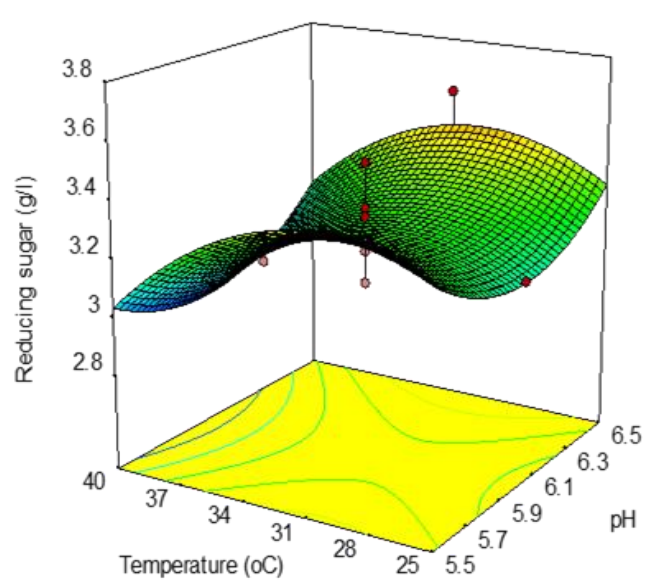

DAY 1

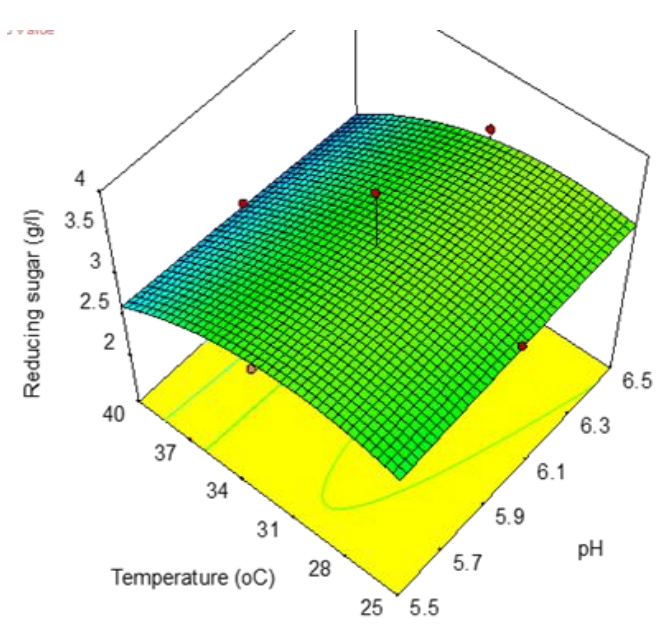

DAY 3

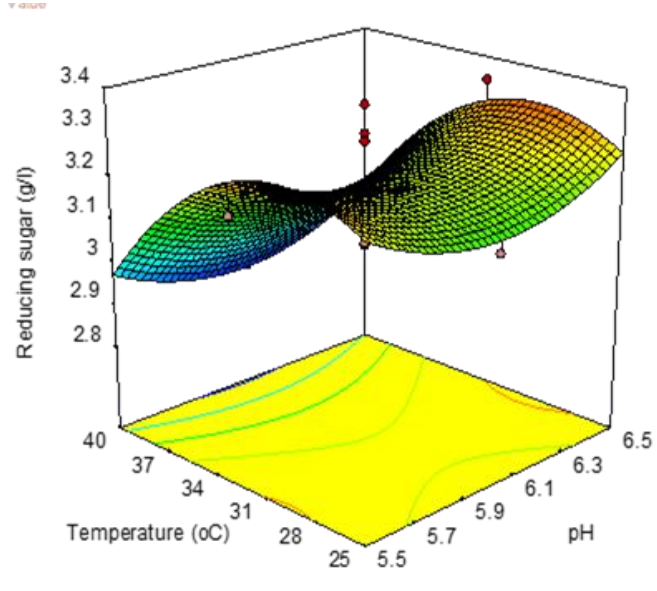

DAY 2

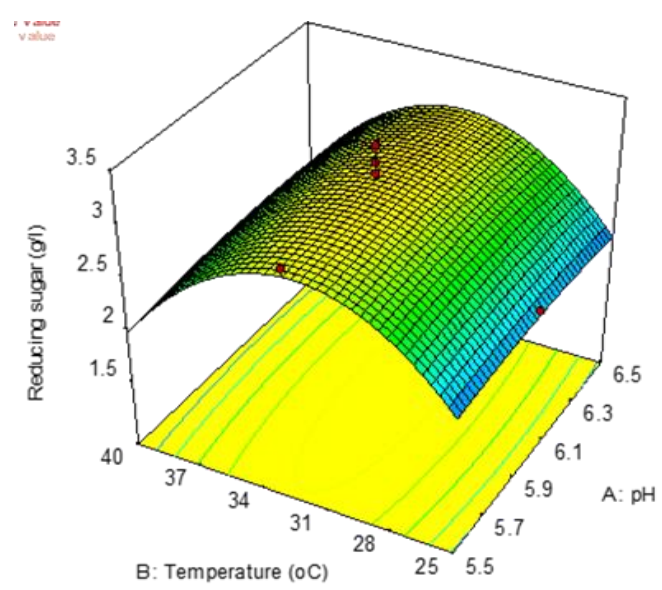

DAY 4

Figure 3 Response surface attributes of reducing sugar from Calabash using Cronobacter malonaticus for 4 days 


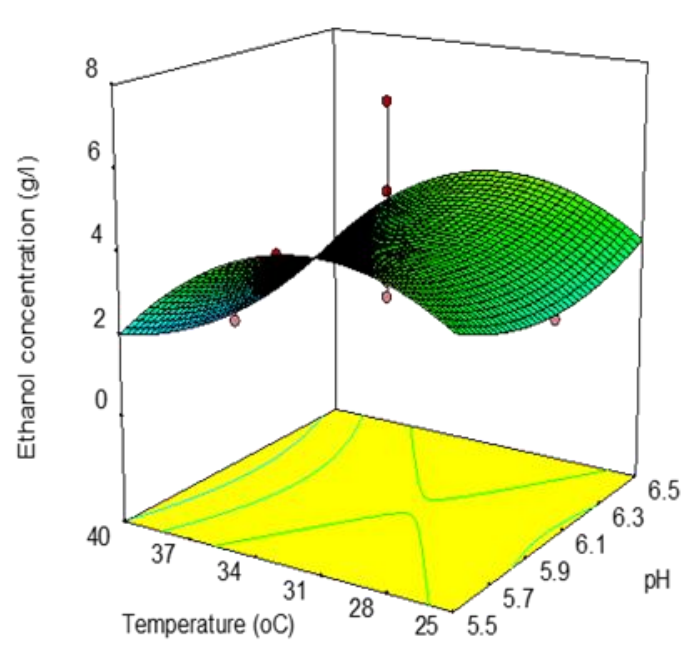

DAY 1

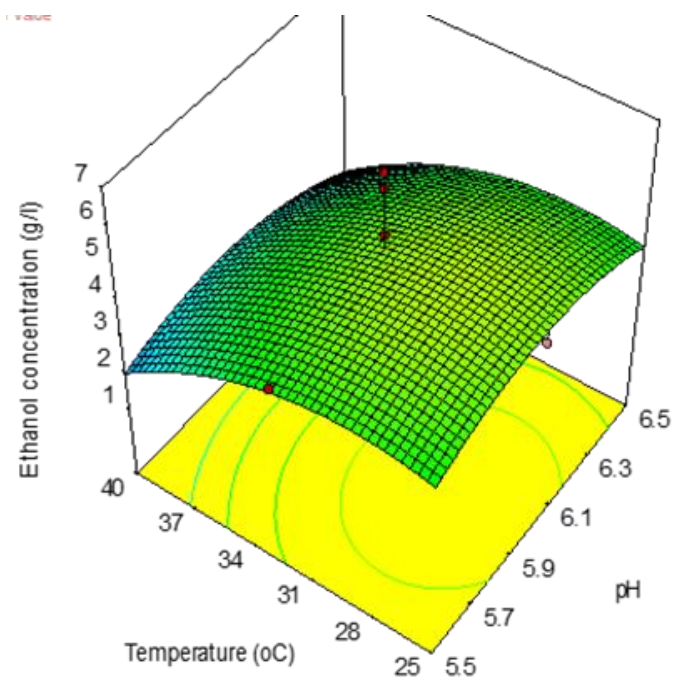

DAY 3

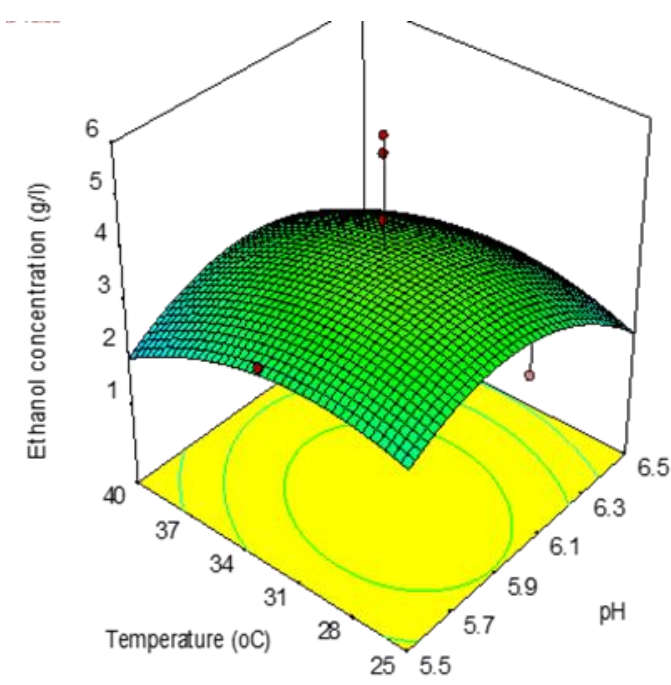

DAY 2

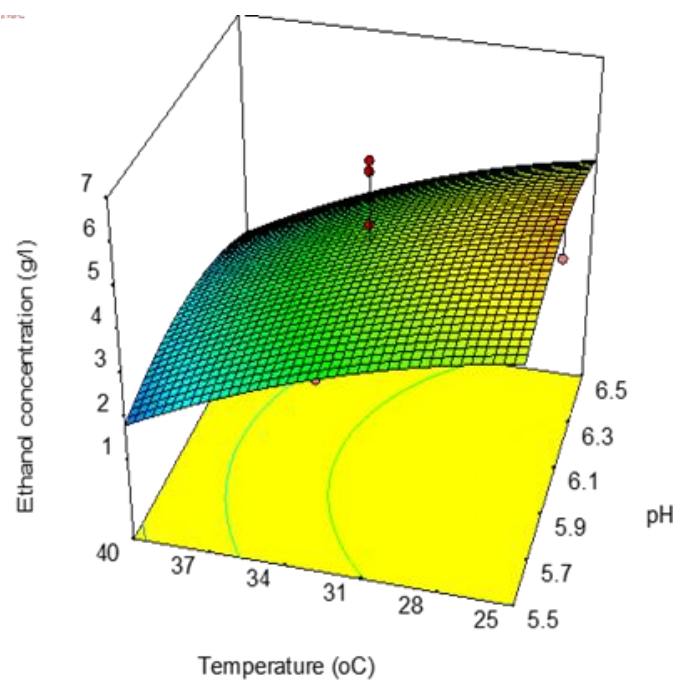

DAY 4

Figure 4 Response surface of ethanol concentration from Calabash using Cronobacter malonaticus for 4 days.

\section{Discussion}

The reducing sugar concentration determined from Calabash juice using glucose calibration curve was $3.22 \mathrm{mg} / \mathrm{ml}$. Free sugar containing juices have been adopted in bioethanol production because pretreatment is not required[14]. Initial sugar concentration is reported to have direct effect on fermentation rate and microbial cells .Inoculum size also affects sugar consumption rate and hence ethanol productivity [14; 15]. Carbohydrate content of Calabash pulp was 87.62\%, and can be hydrolysed to small units (free sugar) for ethanol production [2].

Cronobacter malonaticus, the fermenting microorganism is a member of the Enterobacteriaceae family formerly in the genus Enterobacter.It was isolated from rotten orange and characterized. The use of this organism agrees with reports from [14] that most bacteria have been studied for bioethanol production from sugar containing juices. They are known to produce alcohols, aldehydes and other commodity products from glucose via the 2,3-butanediol fermentative pathway[10;16]. 
The average bioethanol concentration produced for the 4-day period from the 20 runs using the RSM model was $6.47 \%$ $\mathrm{v} / \mathrm{v}$. The optimization process also revealed maximum ethanol concentration of $5.08 \% \mathrm{v} / \mathrm{v}$ at $28^{\circ} \mathrm{C}, \mathrm{pH} 6.08$ and $10 \%$ volume of inoculum.

However, Dates juices fermented at 30oC at natural pH gave maximum concentration of 25\%v/v [14]. [17] Reported that fermented Citrus peel wastes gave $0.33 \% \mathrm{v} / \mathrm{v}$ ethanol. [18] Said that fermented corn cobs with co-culture of Aspergillus niger and Saccharomyces cerevisiae produces $10.08 \% \mathrm{v} / \mathrm{v}$ ethanol from $0.63 \mathrm{mg} / \mathrm{ml}$ reducing sugars after a 7day fermentation period.

Sugarcane juice without supplementation gave $11.0 \mathrm{~g} / \mathrm{l}$ ethanol, whereas addition of yeast extract, thiamine and micronutrients produced 39.4-42.1 g/l ethanol [14]. Optimisation of the process parameters help improve yield [19]. Production of ethanol from Manihot glaziovi using S. cerevisiae, after enzyme hydrolysis gave $0.45 \mathrm{~g}$ ethanol/g reducing sugar, equivalent to $88.61 \%$ theoretical yield[20]. Response surface methodology revealed the optimal conditions for improved yield of bioethanol from Calabash substrate using Cronobacter malonaticus as follows: pH 5.95-6.5; temperature $28-32^{\circ} \mathrm{C}$ and volume of inoculum $10 \%$. This is in line with reports from [14].GC-FID analysis of distillates from C.malonaticus fermentation gave a concentration of $1.1 \mathrm{mg} / \mathrm{l}$ at $32.5^{\circ} \mathrm{C}$, greater than value from control sample. This was done to further authenticate the result obtained in the study. Saccharomyces cerevisiae when used on fruit rinds gave a value of $4.38 \mathrm{~g} / \mathrm{l}$ ethanol from GC analysis [1].

\section{Conclusion}

Cronobacter malonaticus was able to grow and convert Calabash juice to bioethanol. It was isolated from rotten orange, a plant material. The process parameters were optimized using the Response surface methodology and gave results to ascertain that the process can take place on a range of temperatures and $\mathrm{pH}$, when the volume of inoculum is kept constant. The substrate and the inoculum were sourced locally from the environment making it a cheap process to help address our growing energy problems and aid environmental protection. More so, there was no pretreatment of the substrate, which is an expensive venture.

\section{Compliance with ethical standards}

\section{Acknowledgments}

We thank the World Bank African Centre of Excellence for Oil Field Chemicals Research, University of Port Harcourt, for their overall support in this study. Also Tetfund Sponsorship anchored by the Federal University of Technology, Owerri is highly appreciated.

\section{Disclosure of conflict of interest}

The authors declare that there is no conflict of interest.

\section{References}

[1] Bhatia L, Sonia J,Rumana A. An economic and ecological perspective of ethanol production from renewable agro waste: A review. AMB Express.2012;2(65):1-19.

[2] Nwogwugwu NU. Bioconversion of calabash (Crescentia cujete) and fluted pumpkin (Telfairia occidentalis Hook.F) pulp to Ethanol. [Ph.D Thesis]. University of Port Harcourt, Nigeria; 2017.

[3] Igwe JC, Agbaeze KE, Obike AI, Sonde CU. Extraction, Characterization and Determination of ethanol fuel composite qualities of Saccharum officinarum, Pennisetum purpureum_and Costus afer. Asian Journal of plant science and Research.2012; 2 (5): 643-649.

[4] Akponah E, Akpomie 00, Ubogu M. Bioethanol production from cassava effluent using Zymomonas mobilis and Saccharomyces cerevisiae isolated from raffia palm sap. European Journal of Experimental Biology.2013; 3 (4): 247-253.

[5] Bhatia L, Sonia J, Mohd AG. An Ecological and Economical strategies of Preatment to Explore Biovalorization Potential of lignocellulosic agro-wastes for ethanol production. Annual Research and Review in Biology.2014; 4 (21): 3203-3219. 
[6] Gumienna M, Katarzyna S, Malgorzata L, Henry K J, Zbigniew C. Use of saccharomyces cervisia and Zymomonas mobilis for bioethanol production from sugar belt pulp and raw juice. African Journal of Biotechnology.2013; 12(8): 2464-2470.

[7] Edward FG, Dennis GN.Crescentia cujete: Calabash Tree. Series of Environmental Horticulture Department, UF/IFAS Extension, University of Florida, USA; 2014

[8] Ejelonu BC, Lasisi AA, Olaremu AG, Ejelonu OC. The chemical constituents of calabash (Crescentia cujete). African Journal of Biotechnology.2011; 10(84): 19631-19636.

[9] Nwogwugwu NU, Abu GO, Akaranta O. Reducing sugars from agro-waste biomass suitable for industrial applications. Archives of Applied Science Research.2016; 8(8): 37-40.

[10] Escalante WDE, Michiels IC. Influence of butanediol fermentation in spoilage of fresh produce by Enterobacteriaceae.[M.Tech Thesis]. Katholieke Universiteit Leuven; 2011.

[11] Wang C, Liu Y, Jia J, Sivakuma T, Fan T, Gui Z. Optimization of fermentation process for preparation of mulberry fruit wine by response surface methodology. African Journal of Microbiology Research.2013; 7(3): $227-236$.

[12] Nwogwugwu NU, Abu GO, Akaranta O, Chinakwe EC. Application of Response Surface Methodology for Optimizing the Production of Bioethanol from Calabash (Crescentia cujete) Substrate Using Saccharomyces cerevisiae .Journal of Advances in Microbiology.2019;17(2):1-12.

[13] Saitou N, Nei M. (1987). The neighbor-joining method: A new method for reconstructing phylogenetic trees. Molecular Biology and Evolution.1987; 4: 406-425.

[14] Hossain Z, Golam F, Jaya NS, Mohd S A, Rosli H, Amru NB.(2014). Bioethanol Production from Fermentable Sugar Juice.The Scientific World Journal.2014; 2014:1-11.

[15] Thirumalai NT. Bioethanol Production Using Saccharomyces cerevisae Cultivated in Sugarcorn Juice. [ Electronic Thesis and Dissertation Repository].4645. https://ir.lib.uwo.ca/etd/4645.2017.

[16] Khush BA,Ijaz R, Farrukh A, Sabir H, Muhammad HS, Saima M,Muhammad R,Amna B,Sehrish L,Habibullah N. Microbial Production of Ethanol. Materials Research Foundations.2019; 46: 307-334.

[17] Hayder NH, Flayeh HM, Ahmed AW.(2018).Optimization of bioethanol production from biodegradable municipal solid waste using response surface methodology (RSM). Journal of Engineering and Sustainable Development.2018; 12(1):47-65.

[18] Itelima J, Ogbonna A, Pandukur S, Egbere J, Salami A. Simultaneous saccharification and fermentation of corn cobs to bioethanol by co-culture of Aspergillus niger and Saccharomyces cerevisiae. International Journal of Environmental Science and Development.2018; 4(2):239-242.

[19] Togarepi E, Mapiye C, Muchanyereyi C, Dzomba P. Optimization of Fermentation Parameters for Ethanol Production from Ziziphus mauritiana Fruit Pulp Using Saccharomyces cerevisiae (NA33). International Journal of Biochemistry Research and Review.2012; 2(2):60-69.

[20] Abdi HS, Masjuki H H, Hwai CO, Surya D,Arridina SS , Fitranto K, Teuku ,MI M, Aditiya HB. (2017).Optimization of Reducing Sugar Production from Manihot glaziovii Starch Using Response Surface Methodology.Energies.2017; 10(35):1-13. 